the decreased CDAI scores, which are considered universally as unreliable and subjective assessments, remission induced in these patients by the novel treatment is probably only short lived. The high concentrations of soluble TNF receptors show, in our opinion, that these patients have not achieved a stable remission. We have found that the concentration of the soluble TNF receptors in the urine is a useful prognostic indicator for determining the efficacy of treatment and predicting a change in the status of the disease: relapse and remission.

$$
\begin{array}{r}
\text { F HADZISELIMOVIC } \\
\text { University Clinic, } \\
\text { Children's Hospital, } \\
\text { Romergasse } 8, \\
\text { CH-4005 Basle, } \\
\text { Switzerland }
\end{array}
$$

1 Van Dullemen HM, Van Deventer SJH, Hommes DW, Bijl HA, Jansen J, Tytgat GNJ, et al. Treatment of Crohn's disease with anti-tumor necrosis factor chimeric monoclonal antibody (cA2). Gastroenterology 1995; 109: 129-35.

\section{Transfusion for variceal bleeding in cirrhotic patients}

EDITOR,-We wish to comment on the article by McCormick et al (Gut 1995; 36: 100-3) suggesting that secondary haemodynamic changes in the splanchnic circulation after variceal bleeding may contribute to increased risk of further haemorrhage. They suggested that the increased splanchnic blood flow could result either from a reflex portal hyperpressure or to overtransfusion during resuscitation. The reflex portal overpressure could be related to neoroendocrine stimulus induced by the presence of blood in the gut. In a previous trial, we have shown that whole gut irrigation with isotonic mannitol reduced blood transfusion requirements and rebleeding rate after variceal bleeding. ${ }^{1}$ To investigate the possible deleterious influence of blood transfusions, we have compared, in a pilot randomised study, two protocols of transfusion in cirrhotic patients after recent ( $<24$ hours) and severe variceal bleeding (packed cell volume $<27 \%$ ). In group $1(n=43)$, patients were transfused to reach a packed cell volume value of $25 \pm 2 \%$ and in group $2(n=47)$ $32 \pm 2 \%{ }^{2}$ Patients were mainly Child-Pugh grades $\mathbf{B}$ and $\mathrm{C}$ without any difference between the two groups. There were six Child-Pugh A, $20 \mathrm{~B}, 17 \mathrm{C}$ in group 1 and seven $A, 23 \mathrm{~B}$, and $17 \mathrm{C}$ in group 2 . In patients with active bleeding, haemotasis was obtained by balloon tamponade. The percentage of patients with active bleeding was similar $(52 \%)$ in the two groups. No patient received vasoactive drugs. The follow up period was six days after the initial endoscopy performed at admission. Recurrent bleeding was defined by a new bleeding episode, a $3 \%$ or more drop of the packed cell volume value or the lack of correction of the initial value of packed cell volume despite transfusions, or all three. At day 6 , the mean number of blood units received by the patients was 2.6 in group 1 versus 4.4 in group $2(\mathrm{p}<0.001)$. The rebleeding rate was $40 \%$ in group 1 and $48 \%$ in group 2 (NS) and the death rate was $14 \%$ in group 1 and $12 \%$ in group 2 (NS). Complications (hepatorenal failure, sepsis, hepatic encephalopathy) occurred with a similar frequency in the two groups. In this pilot study, the absence of significant benefit with the low transfusion rate is probably due to a beta error. Nevertheless, in accordance with McCormick's opinion, it suggests that limited blood transfusions could reduce the early rebleeding rate in cirrhotic patients with variceal bleeding without deleterious effects. A large multicentre trial is actually in progress to compare the results of the two transfusion protocols in cirrhotic patients with variceal bleeding treated by vasoactive drugs and emergency sclerotherapy.

P HOCHAIN

$\checkmark$ MERLE

$S$ TUIL

P MICHEL

P DUCROTTE

R COLIN

GBPDN, Hôpital Charles Nicolle,

1 rue de Germont,

76031 Rouen Cedex, France

CHU Côte de Nacre 14000 Caen, France

1 Hecketsweiler P, Colin R, Ouvry D, Galmiche JP, Paillot B, Geffroy Y. Le lavage digestif par une solution de mannitol au cours des hémorragies digestives du cirrhotique. Résultats d'une étude contrôlée. Gastroenterol Clin Biol 1978; 2: contrôlee.

2 Tuil S, Bruna T, Dao T, Duhamel C, Tranvouez $\mathrm{JL}$, Guedon $\mathrm{C}$, et al. Influence des transfusions sur le taux de récidives précoces des hémorragies digestives hautes abondantes liées àl'hypertension portale chez le cirrhotique. Etude prospective multicentrique.
Gastroenterol Clin Biol 1993; 17: 165 .

\section{Gastric metaplasia and Helicobacter pylori infection}

EDITOR,-Dr Savarino and his colleagues (Gut 1995; 37: 445-6 [letter]) are not entirely correct in their reference to our paper published in Gut in $1989^{1}$ and subsequent report. ${ }^{2}$ They quote us as 'failing to show any reversal of gastric metaplasia in the duodenum' following medical antisecretory treatment. Although our numbers were small, we reported a noticeable difference between the persistence of metaplasia, as shown by a light and electron microscopy scoring, at the end of one year's maintenance treatment following duodenal ulcer healing with cimetidine 400 mg every night and one year's maintenance treatment with sucralfate $1 \mathrm{~g}$ twice daily. Gastric metaplasia was absent in two of 14 and minimal in three of 14 of the cimetidine group compared with four of 11 and four of 11 respectively of the sucralfate group. It was noted that Helicobacter pylori was absent in those patients with no metaplasia.

In addition, although both groups at the time of the ulcer healing showed a moderate improvement in the mucosal scoring, at the end of the maintenance year the score in four of 14 of the cimetidine group had reverted to their high initial pretreatment score compared with one of 11 of the sucralfate group.

This suggests that treatment that enhances mucosal protection is more likely to enable the duodenal mucosa to revert to normal than reduction of acid secretion.

F I TOVEY

Department of Surgery, London W1P $7 L D$

1 Tovey FI, Husband EM, Yiu Chu Yiu, Baker L, McPhail G, Lewin MR, et al. Comparison of relapse rates and of mucosal abnormalities after healing of duodenal ulceration and after one year's maintenance with cimetidine or sucralfate; a light and elect

Tovey FI, Husband EM, Yiu Chu Yiu, Baker L McPhail G, Lewin MR. Differences in mucosa appearances and in relapse rates in duodenal ulceration treated with sucralfate or cimetidine. Am F Med 1989; 86 (suppl 6A): 141-4.
Faecal stream diversion in patients with collagenous colitis

EDITOR,-Veress et al have published an interesting paper on the microscopic colitis syndrome (Gut 1995; 36: 88-6). Their finding on patient 16 whose increased collagen layer was normal after a temporary loop ileostomy is identical to our previous findings. We have presented experiences of faecal stream diversion in collagenous colitis at both Swedish $^{1}$ and Scandinavian ${ }^{2}$ conferences on gastroenterology. Our original report included five of our own operated cases but was later extended with four other cases who underwent surgery in other Swedish hospitals. These four patients were included in our study after written permission had been obtained from the patients' doctors.

Our main conclusion from these nine operated patients was that faecal stream diversion induced clinical and histopathological remission in collagenous colitis. ${ }^{3}$ After closure of the ileostomy and restoration of intestinal continuity clinical symptoms and the abnormal collagen layer recurred. In a patient who had a sigmoidostomy using the Hartmann procedure, the abnormal collagen layer remained thickened in the proximal colon still exposed to the faecal stream but was normal in the excluded rectosigmoid colon. Later, the sigmoidostomy was replaced by a split ileostomy and at follow up the collagen layer was normal in the whole colon. These findings strongly indicate that a luminal noxious factor may be of pathogenetic importance. ${ }^{1-3}$ The nature of this luminal factor is unknown. Hypothetically, it may remain in the small bowel after faecal stream diversion, which may explain the early relapse seen in some of the patients after restoration of intestinal continuity. ${ }^{3}$ Patient 16 in the study by Veress et al is the same patient IMB in our report. ${ }^{3}$

$$
\begin{array}{r}
\text { G JÄRNEROT } \\
\text { J BOHR } \\
\text { C TYSK } \\
\text { Department of Medicine, } \\
\text { Division of Gastroenterology } \\
\text { S ERIKSSON } \\
\text { Department of Pathology, } \\
\text { Orebro Medical Centre Hospital, } \\
\text { S-701 85 Orebro, Sweden }
\end{array}
$$

1 Bohr J, Eriksson S, Järnerot G, Tysk C. Kollagenskiktet vid kollagen kolit normaliseras efter bortledande av faekalströmmen. (Abstract). Hygiea 1992; 101: 158.

2 Tysk C, Bohr J, Järnerot G, Eriksson $S$. Collagenous colitis is caused by a noxious agent in the faecal stream? Observations from six patients treated surgically. [Abstract]. Scand $\mathcal{F}$ patients treated surgically. [Abstract].
Gastroenterol 1993; 28 (suppl 197): 51 .

3 Järnerot G, Tysk C, Bohr J, Eriksson S. Collagenous colitis and faecal stream diversion. Gastroenterology 1995; 109: 449-55.

\section{Reply}

EDITOR,-Thank you for giving us the opportunity to comment on the letter from Järnerot et al. In 1977-1979 one of us (BV) was working together with Dr C Lindström, who first described collagenous colitis. ${ }^{1}$ In 1982 , we presented our first patient with collagenous colitis at the Meeting of the Swedish Society of Surgeons in Karlstad. ${ }^{2}$ The patient referred to by Järnerot et al (no 16) was included in our first joint report from the Central Hospital in Karlstad and Huddinge University Hospital. Järnerot $e t$ al were unaware that this patient was originally seen by us. The findings described by Järnerot $e t$ al at the time of the preparation of our paper had only been presented as abstracts. 